\title{
Effects of Retarding Fuel Injection Timing on Toxic Organic Pollutant Emissions from Diesel Engines
}

\author{
Yixiu Zhao ${ }^{1}$, Kangping Cui ${ }^{1 *}$, Jingning $\mathrm{Zhu}^{1}$, Shida Chen ${ }^{1}$, Lin-Chi Wang ${ }^{2,3,4^{*}}$, \\ Nicholas Kiprotich Cheruiyot ${ }^{5^{*}}$, Justus Kavita Mutuku ${ }^{5}$ \\ ${ }^{1}$ School of Resources and Environmental Engineering, Hefei University of Technology, Hefei 246011, China \\ ${ }^{2}$ Department of Civil Engineering and Geomatics, Cheng Shiu University, Kaohsiung 83347, Taiwan \\ ${ }^{3}$ Center for Environmental Toxin and Emerging-Contaminant Research, Cheng Shiu University, Kaohsiung 83347, Taiwan \\ ${ }^{4}$ Super Micro Mass Research and Technology Center, Cheng Shiu University, Kaohsiung 83347, Taiwan \\ ${ }^{5}$ Department of Environmental Engineering, National Cheng Kung University, Tainan 70101, Taiwan
}

\begin{abstract}
Retarding the fuel injection timing is an effective strategy for controlling $\mathrm{NO}_{\mathrm{x}}$ emissions from diesel engines. However, the influence of retarding the fuel injection timing on polycyclic aromatic hydrocarbon (PAH) and persistent organic pollutant (POP) emissions has not yet been investigated. In this study, the diesel engine was tested using four of the existing thirteen European steady state cycle (ESC) modes. The fuel injection timing was retarded from $-8^{\circ}$ to $-6^{\circ}$ and the diesel exhaust gas samples were analyzed for PAH and POP emissions. The $\mathrm{NO}_{\mathrm{x}}$ emission factor reduced by $\sim 25 \%$ when the fuel injection timing was retarded. However, the strategy had a negative effect on combustion efficiency. The carbon monoxide $(\mathrm{CO})$ and particulate matter (PM) emissions were 1.4 and 1.2 times higher for the $-6^{\circ}$ scenario, respectively. The emission factors of all the toxic organic pollutants increased drastically when the fuel injection timing was retarded. For instance, the emission factors of $\mathrm{PAH}$ and polychlorinated dibenzo- $p$-dioxin/dibenzofuran $(\mathrm{PCDD} / \mathrm{F})$ for the $-6^{\circ}$ scenario, based on BaPeq and WHO-TEQ, were 22 and 10 times higher than for the $-8^{\circ}$ scenario. The retardation had more influence on these pollutants in the particle-phase than in gas-phase. The resultant negative impact on combustion increased the emissions of products of incomplete combustion, enhancing the potential of POP formation via de novo synthesis. The study concludes that although retarding the fuel injection timing leads to a decrease in $\mathrm{NO}_{\mathrm{x}}$ emissions from diesel engines, it also results in an increase in PAH and POP emissions.
\end{abstract}

Keywords: Diesel engine; Retarding injection timing; PAHs; POPs.

\section{INTRODUCTION}

Diesel internal combustion engines are widely used in light and heavy transport, agricultural machinery, as well as industrial use due to their high power output coupled with high fuel efficiency and subsequently lower $\mathrm{CO}_{2}$ emissions (Alriksson and Denbratt, 2006; Dober et al., 2008). Despite these advantages, emissions from diesel engines are significant sources of nitrogen oxides $\left(\mathrm{NO}_{\mathrm{x}}\right)$ and particulate matter (PM). Besides acting as precursors for PM and ground level $\mathrm{O}_{3}, \mathrm{NO}_{\mathrm{x}}$ from a diesel engine are believed to cause adverse effects to human health (Bell et al., 2004; Khaniabadi et al., 2017). In addition to the conventional air

\footnotetext{
* Corresponding authors.

E-mail address: lcwang@csu.edu.tw (L.C. Wang); cuikangping@163.com (K. Cui); kipnichols26@gmail.com (N.K. Cheruiyot)
}

pollutants, diesel engines also emit toxic and carcinogenic polycyclic aromatic hydrocarbons (PAHs) and persistent organic pollutants (POPs) including; polychlorinated dibenzo$p$-dioxins and dibenzofurans (PCDD/Fs), polychlorinated biphenyls (PCBs), polybrominated dibenzo- $p$-dioxins and dibenzofurans (PBDD/Fs), polybrominated biphenyls (PBBs), and polybrominated diphenyl ethers (PBDEs) (McDonald et al., 2011; Chang et al., 2014b; Mwangi et al., 2015; Cheruiyot et al., 2016; Chen et al., 2017c; Lai et al., 2017).

Stricter emission standards on the conventional pollutants like $\mathrm{NO}_{\mathrm{x}}$ and $\mathrm{PM}$ has led to the adoption of aftertreatment technologies over the years. The technologies and strategies employed to reduce $\mathrm{NO}_{\mathrm{x}}$ emissions from diesel engines accomplish this fete through either one or more of these means; reducing the peak temperature, reducing the residence time of combustion products in high temperature zones and reducing the Air-to-fuel (A/F) ratio (Sindhu et al., 2018). Some of the aftertreatment technologies and strategies employed include $\mathrm{NO}_{\mathrm{x}}$ traps, exhaust gas recirculation (EGR), selective catalytic reduction (SCR) and retarding fuel 
injection timing (Koebel et al., 2000; Kouremenos et al., 2001; Agarwal et al., 2011; Diao et al., 2018; Chen et al., 2019).

Retarding the fuel injection timing reduces $\mathrm{NO}_{\mathrm{x}}$ formation in diesel engines by shifting the combustion event so that the peak pressures occur when the piston is well beyond the top-dead-center (TDC) resulting in lower pressure and temperature (Sayin and Canakci, 2009; Sindhu et al., 2018). At constant engine load, Sayin and Canakci (2009) reported a $\sim 30 \%$ decrease in $\mathrm{NO}_{\mathrm{x}}$ emissions when the injection time was retarded by $5^{\circ}$. Mani and Nagarajan (2009) also reported a decrease in $\mathrm{NO}_{\mathrm{x}}$ emissions with the retardation of the injection timing from the standard $23^{\circ}$ to $14^{\circ}$ before TDC. Specifically, they ranged from $8.9 \mathrm{~g} \mathrm{~kW}-\mathrm{h}^{-1}$ to 16.35 $\mathrm{g} \mathrm{kW}-\mathrm{h}^{-1}$ for standard injection and from $8.56 \mathrm{~g} \mathrm{~kW}-\mathrm{h}^{-1}$ to $14.63 \mathrm{~g} \mathrm{~kW}^{-1} \mathrm{~h}^{-1}$ for retarded injection at $100 \%$ to $0 \%$ engine loads, respectively. In an investigation carried out using different biodiesel blends, maximum $\mathrm{NO}_{\mathrm{x}}$ emissions observed for B20 at $21^{\circ}$ BTDC were lower than those observes at $24^{\circ} \mathrm{BTDC}$. Overall, for all loads ranging between $100 \%$ to $0 \%, \mathrm{NO}_{\mathrm{x}}$ emission factors varied as follows; $27^{\circ}$ $\mathrm{BTDC}>24^{\circ} \mathrm{BTDC}>21^{\circ}$ BTDC (Gnanasekaran et al., 2016).

However, retarding the injection time leads to significant trade-offs between $\mathrm{NO}_{\mathrm{x}}$ and particulate matter (PM), as well as the fuel consumption because the lower temperatures result in incomplete combustion of the fuel (Kouremenos et al., 2001; Zeng et al., 2006; Sayin and Canakci, 2009; Agarwal et al., 2014). Several studies reported increase on emissions of products of incomplete combustion (PIC) including soot, carbon monoxide and hydrocarbon during fuel timing retardation (Kouremenos et al., 2001; Sayin and Canakci, 2009; Liu et al., 2014). This impact on combustion quality might also influence POP emissions from diesel engines since some of these PICs have been shown to act as precursors for the formation of POPs (Addink and Altwicker, 2004). However, to the best of our knowledge, this relationship between injection timing and POP emissions has not yet been investigated.

Therefore, the objective of this research is to study the effect of retarding the fuel injection timings on $\mathrm{PAH}$ and POP emissions from a heavy-duty diesel engine (HDDE). The concentrations, congener profiles, and emission factors of PAHs, PCDD/Fs, PCBs, PBDD/Fs and PBDEs from the HDDE exhaust at $-8^{\circ}$ and $-6^{\circ}$ injection timings were collected and compared. The results from this research would shade light into the effects of conventional pollutant treatment technologies and strategies on PAH and POP emissions from diesel engines.

\section{METHODS AND MATERIALS}

\section{Diesel Engine and Test Fuel}

This experiment was performed using a Hino W06E, which is a heavy-duty diesel engine with a direct fuel injection system. Details of the specifications for the diesel engine are given in Table 1, including engine configuration, fuel injection system, compression ratio, injection timing and working boundary conditions. The torque and speed of the engine were monitored using the Schenck W230 engine dynamometer. The engine was tested using four of the existing thirteen European steady state cycle (ESC) modes: mode 1 (750 rpm, 0\% load, $0 \mathrm{Nm}$ ), mode 2 (1650 rpm, $100 \%$ load, $360 \mathrm{Nm}$ ), mode 7 (1650 rpm, 25\% load, $90 \mathrm{Nm}$ ) and mode 11 (1925 rpm, 25\% load, $96.2 \mathrm{Nm}$ ). A commercial fuel blend of $98 \%$ fossil diesel and $2 \%$ biodiesel (B2) was used as the test fuel for this investigation.

\section{Test Methods and Sampling Procedures}

In order to carry out the tests on the exhaust gases, samples were collected at two different injection timings, at $-8^{\circ}$ and $-6^{\circ}$, which represent the default engine setting and the retarded injection timing, respectively. Before each sampling, the engine was preheated for 30 minutes and for at least 3 minutes between the different test modes. During the entire testing cycle, samples of the exhaust gases from

Table 1. Properties of the diesel engine under investigation.

\begin{tabular}{ll}
\hline Item & Hino W06E \\
\hline Configuration & In-line 6-cylinder \\
Stroke & $118 \mathrm{~mm}$ \\
Bore & $104 \mathrm{~mm}$ \\
Air intake & Naturally aspirated \\
Compression ratio & 17.9 \\
Type of fuel injection system & Bosch A type \\
Injection type & Direct injection \\
Fuel injection pressure & $21560 \mathrm{kPa}$ \\
Injection timing & $15^{\circ} \mathrm{Before}$ top dead center \\
Displacement & $6.0 \mathrm{~L}$ \\
Max torque & $412 \mathrm{Nm} @ 1800 \mathrm{rpm}$ \\
Max power & $121 \mathrm{~kW} @ 3000 \mathrm{rpm}$ \\
EGR & No \\
Boundary condition & \\
Ambient air temperature & $30-40^{\circ} \mathrm{C}$ \\
Ambient air pressure & Approximate $101 \mathrm{kPa}(1 \mathrm{~atm})$ \\
Ambient air humidity & $60-70 \%$ \\
\hline
\end{tabular}


the diesel engine were collected directly at a constant velocity. The components of the sampling system included a glass fiber filter, flow meter, condenser, two-stage glass cartridges, and a pump. The glass fiber filter was applied for the collection of particulate phase pollutants. A set of cooling devices positioned immediately before the twostage glass cartridges was used to lower the exhaust gas temperature to below $5^{\circ} \mathrm{C}$ and remove moisture from the exhaust gas. The toxic pollutants in their gaseous phase were collected through the two-stage glass cartridges. Structurally, the cartridges were composed of $5.0 \mathrm{~cm}$ (about $20 \mathrm{~g}$ ) of XAD-2 resin packed inside a tube and held in place by two $2.5 \mathrm{~cm}$ polyurethane foam plugs.

Samples from four runs were combined into one to ensure the pollutant concentrations were above the detection limit. The total sampling time was $\sim 80$ minutes with each ESC mode requiring about $\sim 20$ minutes each. The sample volumes were normalized to standard temperature and pressure (273 $\mathrm{K}$ and $760 \mathrm{mmHg}$, respectively) and denoted as $\mathrm{Nm}^{-3}$.

\section{Analytical Procedures}

To determine the mass of particulate matter in the respective samples, a Precisa XR 205SM-DR balance with a sensitivity of $0.01 \mathrm{mg}$ was applied for weighing the filters. The concentration of $\mathrm{NO}_{\mathrm{x}}$ in the exhaust gas was determined using a Rosemount Model 951A NO/NO analyzer (Chang et al., 2014b).

Each POP sample was extracted by a Soxhlet extractor using a mixed solvent (n-hexane and dichloromethane; vol/vol, 1:1; $250 \mathrm{~mL}$ each) for 24 hours. Internal standards of PAHs, PCDD/Fs, PCBs, PBDD/Fs, and PBDEs were spiked into the extract to monitor the sample recoveries. The extracts were concentrated by gently purging a stream of ultra-pure nitrogen and then cleaned up by passing through a silica gel column. The effluents were re-concentrated to exactly $1 \mathrm{~mL}$. PAH contents were detected with gas chromatography/mass spectrometry (GC/MS). The detailed PAH analytical procedures are given in our previous works (Wang et al., 2007, 2009)

After the GC/MS analysis, the solutions in the vials were then analyzed for seventeen 2,3,7,8-substituted PCDD/Fs, twelve dioxin-like PCBs, twelve 2,3,7,8-substituted PBDD/Fs and fourteen PBDE congeners. In brief, the sample solution was treated with concentrated sulfuric acid, followed by a series of sample cleanup and fractionation procedures, including a multi-layered silica column, alumina column, and an activated carbon column. During the aluminacolumn cleanup, non-planar PCBs were first eluted with $25 \mathrm{~mL}$ hexane and then with $15 \mathrm{~mL} \mathrm{DCM} /$ hexane $(4 / 96$, $\mathrm{v} / \mathrm{v}$ ) prior to their trapping by activated carbon. The activated carbon column was sequentially eluted with $25 \mathrm{~mL}$ dichloromethane/hexane (40/60, v/v) for extracting PBDEs and planar PCBs, which was followed by $40 \mathrm{~mL}$ of toluene for extracting PCDD/Fs and PBDD/Fs. Before instrumental analyses, the planar and non-planar PCB eluates were mixed together. The detailed analytical procedures are described in more detail in previous works (Chang et al., 2014a; Wu et al., 2014).

\section{Instrumental Analysis}

The GC/MS (Agilent 5890A and Agilent 5975) for PAH measurement was equipped with a capillary column (HP Ultra $2-50 \mathrm{~m} \times 0.32 \mathrm{~mm} \times 0.17 \mu \mathrm{m})$. The operating conditions were an injection volume of $1 \mu \mathrm{L}$; splitless injection at $300^{\circ} \mathrm{C}$; ion source temperature at $310^{\circ} \mathrm{C}$; oven temperature held at $45^{\circ} \mathrm{C}$ for $1 \mathrm{~min}$, ramped from 45 to $100^{\circ} \mathrm{C}$ in $5 \mathrm{~min}$, ramped from 100 to $320^{\circ} \mathrm{C}$ at $8^{\circ} \mathrm{C} \mathrm{min}{ }^{-1}$ and held at $320^{\circ} \mathrm{C}$ for $15 \mathrm{~min}$. The masses of the primary and secondary PAH ions were determined by using the scan mode for pure PAH standards. The PAHs were qualified by using the selected ion monitoring (SIM) mode.

A high-resolution gas chromatography/high-resolution mass spectrometer (HRGC/HRMS) was used for the POP analyses. The HRGC (Hewlett-Packard 6970 Series gas, CA) was equipped with a silica capillary column (J\&W Scientific, CA) and a splitless injector, while the HRMS (Micromass Autospec Ultima, Manchester, UK) was equipped with a positive electron impact $(\mathrm{EI}+)$ source. The SIM mode was used with a resolving power of 10,000 . The electron energy and the source temperature were specified at $35 \mathrm{eV}$ and $250^{\circ} \mathrm{C}$, respectively. Each analyte requires an individual injection, i.e., one exhaust sample needs six injections for the analyses of PCDD/Fs, PCBs, PCDEs, PBDD/Fs, PBBs and PBDEs. The detailed instrumental analysis parameters are given in previous works (Wang et al., 2003; Chang et al., 2013; Wu et al., 2014).

\section{Quality Assurance and Quality Control $(Q A / Q C)$}

Prior to samplings, the glass fiber filters were placed in an oven at $450^{\circ} \mathrm{C}$ for $8 \mathrm{~h}$ to burn off all organic pollutants. Field and laboratory blank controls were incorporated into this study. Compared with the corresponding exhaust samples, the POPs in these blank samples were all lesser than $0.5 \%$ of total POPs in the real samples, except for PBDEs, which were $<2 \%$ of real samples. All these blank samples were negligible compared with the corresponding exhaust samples.

For POPs, the surrogate standards were spiked into the cartridges and their recoveries were used to analyze the breakthroughs of POPs in the samples. The sampling probe and other components of the sample train were rinsed after each sampling. The nozzle, probe and probe lines were rinsed three times with methylene chloride and then three times with toluene. The rinsate were collected and included for POPs analyses. For each diesel engine test, a prior leak check was carried out between the inlet of the filter holder and the outlet of the flow meter. During the pretreatment procedures of sample analyses, both the internal and recovery standards were added to the sample. The recoveries of precision and recovery (PAR), surrogate, and internal labeled standards of POPs all met the respective standards.

\section{RESULTS AND DISCUSSION}

\section{Emission Factors of Conventional Pollutants}

Table 2 presents the emission factors of CO, PM and $\mathrm{NO}_{\mathrm{x}}$ from the diesel engine at the two different fuel 
injection timings. As expected, retarding the fuel injection timing resulted in lower $\mathrm{NO}_{\mathrm{x}}$ emissions. The emission factor of $\mathrm{NO}_{\mathrm{x}}$ was $24.8 \%$ lower for $-6^{\circ}$ injection timing when compared to $-8^{\circ}$ scenario. Similar decreases have been reported in previous studies (Agarwal et al., 2013; Gnanasekaran et al., 2016). However, since retarding the fuel injection timing has a negative impact on combustion, the emission factors of $\mathrm{CO}$ and PM, which are indicators of combustion efficiency, were 1.4 and 1.2 times higher for $-6^{\circ}$ than for $-8^{\circ}$ fuel injection timing, respectively.

\section{PAH and POP Concentrations and Gas- and Particle- phase Partitioning}

Sampling artifacts can result in over- or underestimation of semi-volatile organic compounds because of their wide range of gas- and particle-phase partitioning (Cheruiyot et al., 2015; Melymuk et al., 2016). Table 3 presents the PAH and POP contents in the particles collected by the sampling filters and from the inner surface of the exhaust duct. The contents in the particles collected by the sampling filter were generally higher than those from particles collected from the inner surface of the duct. For instance, the PAH mass contents in the particulates collected by sampling filter were $\sim 3$ and 5 times higher than those in the inner surface of the duct for $-8^{\circ}$ and $-6^{\circ}$ fuel injection timings, respectively. For PCDD/F toxicity, the difference was even increase to $\sim 13$ times during the $-8^{\circ}$ scenario. This observed difference could be because the gas-phase congeners were adsorbed on to the particulates collected by the filter and on the filter itself. Therefore, to eliminate the bias caused by the sampling artifacts, the PAH and POP concentrations were corrected using a similar method discussed in our previous studies (Kuo et al., 2012; Chen et al., 2017c).

The corrected gas- and particle-phase PAH and POP concentrations are presented in Table 4. The gas-phase
PAHs and POPs were found to dominate diesel engine exhaust during both fuel injection timings. That is because the high exhaust temperature and the formation of POPs were through homogenous gas-phase pathway (Chen et al., 2017c).

The concentrations during the $-6^{\circ}$ injection timing were drastically higher for all toxic organic pollutants than during $-8^{\circ}$. For instance, the mass concentrations of PAHs and POPs during the $-6^{\circ}$ were $1.1-63$ times higher than those during $-8^{\circ}$ injection timing. Retarding the injection time reduces the combustion temperature which leads to incomplete combustion. This assertion is supported by the increased emission of $\mathrm{CO}$ and PM in our study. The lower combustion efficiency results in a generation of products of incomplete combustion including these toxic compounds and their precursors. Therefore, it can be concluded that retarding the fuel injection timing results in an increase in PAH and POP concentrations from diesel engines.

Comparing the $-6^{\circ} /-8^{\circ}$ ratios of particle-phase with those of gas-phase, we found that retarding the injection timing had more influence on these toxic pollutants in particlephase, except for PCBs. For instance, $-6^{\circ} /-8^{\circ}$ ratios of the gas- and particle-phase PCDD/F were 1.0 and 3.3 while those of PBDD/Fs were 1.7 and 28, respectively. That is because the negative effect on combustion that resulted from the injection timing retardation led to an increase in PM and other products of incomplete combustion including soot. Thereby, providing the necessary carbon matrix for POP formation via de novo synthesis.

\section{$P A H$ and POP Emission Factors}

The emission factors of the diesel engine during the two injection timings were calculated and are presented in Table 5. Retarding the injection timing lead to a dramatic increase in PAH and POP emission factors. For instance, the mass emission factors of PAHs, PCDD/Fs, PCBs, PBDD/Fs,

Table 2. Emission factors of $\mathrm{CO}, \mathrm{PM}$ and $\mathrm{NO}_{\mathrm{x}}$ from the diesel engine.

\begin{tabular}{lllll}
\hline & & $\mathrm{CO}\left(\mathrm{g} \mathrm{kW}^{-1}\right)$ & $\mathrm{PM}\left(\mathrm{g} \mathrm{kW}-\mathrm{h}^{-1}\right)$ & $\mathrm{NO}_{\mathrm{x}}\left(\mathrm{g} \mathrm{kW}^{-1} \mathrm{~h}^{-1}\right)$ \\
\hline \multirow{2}{*}{ Injection Timing } & $-6^{\circ}$ & 4.69 & 0.62 & 4.44 \\
& $-8^{\circ}$ & 3.28 & 0.50 & 5.91 \\
\hline
\end{tabular}

Table 3. PAH and POP contents in the particles collected by the sampling filters and collected from the inner surface of the duct.

\begin{tabular}{|c|c|c|c|c|c|}
\hline & & \multicolumn{2}{|c|}{$\begin{array}{l}\text { particle collected by the } \\
\text { sampling filter }\end{array}$} & \multicolumn{2}{|c|}{$\begin{array}{l}\text { particle collected from inner } \\
\text { surface of duct }\end{array}$} \\
\hline & & $-8^{\circ}$ & $-6^{\circ}$ & $-8^{\circ}$ & $-6^{\circ}$ \\
\hline \multirow[t]{2}{*}{ PAHs } & Mass $\left(\mu \mathrm{g} \mathrm{g}^{-1}\right)$ & 174 & 92.3 & 52.4 & 18.6 \\
\hline & $\mathrm{BaP}_{\mathrm{eq}}\left(\mu \mathrm{g} \mathrm{g}^{-1}\right)$ & 11.7 & 73.8 & 0.0544 & 0.302 \\
\hline \multirow[t]{2}{*}{$\mathrm{PCDD} / \mathrm{Fs}$} & $\operatorname{Mass}\left(\mathrm{pg} \mathrm{g}^{-1}\right)$ & 3746 & 369 & 126 & 90.3 \\
\hline & WHO-TEQ (pg WHO-TEQ g ${ }^{-1}$ ) & 15.0 & 38.6 & 1.13 & 8.18 \\
\hline \multirow[t]{2}{*}{ PCBs } & $\operatorname{Mass}\left(\mathrm{pg} \mathrm{g}^{-1}\right)$ & NA & 55.3 & 23.5 & 13.5 \\
\hline & WHO-TEQ (pg WHO-TEQ g ${ }^{-1}$ ) & NA & 3.96 & 0.00218 & 0.839 \\
\hline \multirow[t]{2}{*}{$\mathrm{PBDD} / \mathrm{Fs}$} & $\operatorname{Mass}\left(\mathrm{pg} \mathrm{g}^{-1}\right)$ & 2497 & 1797 & 88.9 & 175 \\
\hline & WHO-TEQ (pg WHO-TEQ g ${ }^{-1}$ ) & 6.09 & 18.0 & 0.453 & 4.75 \\
\hline PBBs & Mass (pg g $\left.{ }^{-1}\right)$ & 122 & NA & NA & NA \\
\hline PBDEs & Mass (ng g $\left.{ }^{-1}\right)$ & 139 & 1114 & 20.0 & 45.0 \\
\hline
\end{tabular}


Table 4. Corrected concentrations of toxic organic pollutants in the exhaust gas.

\begin{tabular}{|c|c|c|c|c|c|c|c|c|c|c|}
\hline \multirow{2}{*}{\multicolumn{2}{|c|}{ Toxic organic pollutants }} & \multicolumn{3}{|c|}{ Gas-phase } & \multicolumn{3}{|c|}{ Particle-phase } & \multicolumn{3}{|c|}{ Total } \\
\hline & & \multirow{2}{*}{$\begin{array}{c}-8^{\circ} \\
23.9\end{array}$} & \multirow{2}{*}{$\frac{-6^{\circ}}{34.5}$} & \multirow{2}{*}{$\begin{array}{l}-6^{\circ} /-8^{\circ} \\
\text { Ratio } \\
1.4\end{array}$} & \multirow{2}{*}{$\frac{-8^{\circ}}{0.182}$} & \multirow{2}{*}{$\frac{-6^{\circ}}{0.341}$} & \multirow{2}{*}{$\begin{array}{l}-6^{\circ} /-8^{\circ} \\
\text { Ratio } \\
1.9\end{array}$} & \multirow{2}{*}{$\frac{-8^{\circ}}{24.1}$} & \multirow{2}{*}{$\begin{array}{l}-6^{\circ} \\
34.8\end{array}$} & \multirow{2}{*}{$\begin{array}{l}-6^{\circ} /-8^{\circ} \\
\text { Ratio } \\
1.4\end{array}$} \\
\hline PAHs & $\operatorname{Mass}\left(\mu \mathrm{g} \mathrm{Nm}^{-3}\right)$ & & & & & & & & & \\
\hline & total BaPeq $\left(\mu \mathrm{g} \mathrm{Nm}{ }^{-3}\right)$ & 0.0644 & 1.39 & 22 & 0.000189 & 0.00554 & 29 & 0.0646 & 1.4 & 22 \\
\hline \multirow[t]{2}{*}{$\mathrm{PCDD} / \mathrm{Fs}$} & $\operatorname{Mass}\left(p g \mathrm{Nm}^{-3}\right)$ & 29.8 & 30.2 & 1 & 0.501 & 1.65 & 3.3 & 30.3 & 31.8 & 1.1 \\
\hline & $\begin{array}{l}\text { WHO-TEQ } \\
\left(\text { pg WHO-TEQ Nm }{ }^{-3}\right)\end{array}$ & 0.144 & 2.75 & 19 & 0.0323 & 0.15 & 4.6 & 0.294 & 2.9 & 9.9 \\
\hline \multirow[t]{2}{*}{ PCBs } & $\operatorname{Mass}\left(\mathrm{pg} \mathrm{Nm}{ }^{-3}\right)$ & 5.27 & 51.8 & 9.8 & 0.0815 & 0.248 & 3 & 5.35 & 52 & 9.7 \\
\hline & $\begin{array}{l}\text { WHO-TEQ } \\
\left(\text { pg WHO-TEQ Nm }{ }^{-3} \text { ) }\right.\end{array}$ & 0.205 & 0.419 & 2 & N.D. & N.D. & - & 0.205 & 0.419 & 2 \\
\hline \multirow[t]{2}{*}{$\mathrm{PBDD} / \mathrm{Fs}$} & mass $\left(\mathrm{pg} \mathrm{Nm}{ }^{-3}\right)$ & 20.4 & 34.1 & 1.7 & 0.308 & 8.72 & 28 & 20.7 & 42.8 & 2.1 \\
\hline & $\begin{array}{l}\text { WHO-TEQ } \\
\left(\text { pg WHO-TEQ Nm }{ }^{-3}\right)\end{array}$ & 0.0579 & 0.341 & 5.9 & 0.00157 & 0.0872 & 56 & 0.0595 & 0.428 & 7.2 \\
\hline PBBs & Mass (pg Nm ${ }^{-3}$ ) & 1.09 & 68.2 & 63 & N.D. & N.D. & - & 1.09 & 68.2 & 63 \\
\hline PBDEs & Mass (ng Nm$\left.{ }^{-3}\right)$ & 3.72 & 26.6 & 7.2 & 0.069 & 0.824 & 11.9 & 3.79 & 27.4 & 7.2 \\
\hline
\end{tabular}

Table 5. Emission factors for the toxic organic pollutants in the diesel engine exhaust gas.

\begin{tabular}{|c|c|c|c|c|}
\hline & & & Inje & \\
\hline & & $-8^{\circ}$ & $-6^{\circ}$ & $-6^{\circ} /-8^{\circ}$ ratio \\
\hline PAHs & $\operatorname{Mass}\left(\mathrm{g} \mathrm{kW}^{-1} \mathrm{~h}^{-1}\right)$ & 252 & 361 & 1.4 \\
\hline & Total-BaPeq $\left(\mu \mathrm{g} \mathrm{kW}-\mathrm{h}^{-1}\right)$ & 0.676 & 14.5 & 22 \\
\hline $\mathrm{PCDD} / \mathrm{Fs}$ & 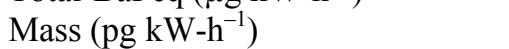 & 318 & 330 & 1 \\
\hline & Total TEQ (pg WHO-TEQ kW- $\mathrm{h}^{-1}$ ) & 3.05 & 30.1 & 9.9 \\
\hline PCBs & Mass (pg kW-h $\left.{ }^{-1}\right)$ & 56 & 539 & 9.6 \\
\hline & Total TEQ (pg WHO-TEQ kW-h ${ }^{-1}$ ) & 2.15 & 4.34 & 2 \\
\hline $\mathrm{PBDD} / \mathrm{Fs}$ & Mass (pg kW-h $\left.{ }^{-1}\right)$ & 218 & 444 & 2 \\
\hline & Total TEQ (pg WHO-TEQ kW-h ${ }^{-1}$ ) & 0.623 & 4.44 & 7.1 \\
\hline PBBs & Mass (pg kW-h $\left.{ }^{-1}\right)$ & 11.4 & 707 & 62 \\
\hline PBDEs & Mass (ng kW-h $\left.{ }^{-1}\right)$ & 39.7 & 284 & 7.2 \\
\hline
\end{tabular}

PBBs and PBDEs during $-6^{\circ}$ injection timing were $1.4,1$, $10,2,62$, and 7 times higher than those of $-8^{\circ}$ injection timing, respectively. The total toxic $(\mathrm{PCDD} / \mathrm{Fs}+\mathrm{PCBs}+$ PBDD/Fs) emission factors during the $-8^{\circ}$ and $-6^{\circ}$ injection timing were $6 \mathrm{pg}$ WHO-TEQ $\mathrm{kW}-\mathrm{h}^{-1}$ and $39 \mathrm{pg}$ WHOTEQ $\mathrm{kW}-\mathrm{h}^{-1}$, respectively. The results show that there is a similar trade-off relationship between the toxic organic pollutants and $\mathrm{NO}_{\mathrm{x}}$ as the $\mathrm{PM}$ and $\mathrm{NO}_{\mathrm{x}}$ emissions during $\mathrm{NO}_{\mathrm{x}}$ treatment strategies. $\mathrm{NO}_{\mathrm{x}}$ reduction requiring lower combustion temperature in turn causes incomplete combustion which resulted in higher emissions of PM and toxic organic pollutants.

\section{$P A H$ and POP Congener Profiles}

The PAH and POP mass congener profiles of the two different injection timings are shown in Fig. 1. The predominant PAH for the two scenarios was Nap which is similar to published results on diesel exhaust emissions (He et al., 2010; Chang et al., 2014b; Chen et al., 2017a, c). Nap, PA and Pyr accounted for $\sim 92 \%$ and $\sim 90 \%$ of the total congeners for the $-6^{\circ}$ and $-8^{\circ}$ fuel injection timing, respectively. The total mass fraction of the six most toxic PAH congeners with TEF values of 0.1 and 1 were $2.7 \%$ and $2.0 \%$ for the $-6^{\circ}$ and $-8^{\circ}$ scenarios, respectively. This resulted in the higher $\mathrm{BaP}_{\mathrm{eq}}$ concentration observed during the $-6^{\circ}$ injection timing scenario.

OCDD, OCDF, 1,2,3,4,6,7,8-HpCDD/Fs, TeCDF, and PeCDFs were the predominant PCDD/Fs. This is similar to other HDDEs exhaust emissions (Laroo et al., 2012; Chang et al., 2014a; Cheruiyot et al., 2017). The PCDD/F congener profile for the $-6^{\circ}$ scenario was found to contain a higher fraction of lower chlorinated PCDFs, while the fractions of higher chlorinated congeners were lower than the $-8^{\circ}$ scenario. For instance, for TeCDFs increased from $3.9 \%$ to $7.7 \%$ while PeCDFs from $10.8 \%$ to $12.8 \%$. This increase of lower chlorinated PCDFs is an indication of POP formation via de novo synthesis (Iino et al., 1999; Ni et al., 2009). This led to the observed higher toxic concentrations observed during $-6^{\circ}$ scenario.

The predominant PCB congeners were PCB-118, PCB-77, and PCB 105, while 1,2,3,4,6,7,8-HpBDF, OBDF, PBB-15, and BDE-209 were the major brominated congeners. These congeners are also abundant in most combustion sources (Wang et al., 2010a, b, 2011; Chang et al., 2013; Chang et al., 2014b; Kuo et al., 2015; Chen et al., 2017b, c; Redfern et al., 2017a, b) and environmental media (Mwangi et al., 2016). PCB-118 and PCB-77 contributed to $85 \%$ of the total congener for $-6^{\circ}$ scenario and $49 \%$ for $-8^{\circ}$ injection timing. 


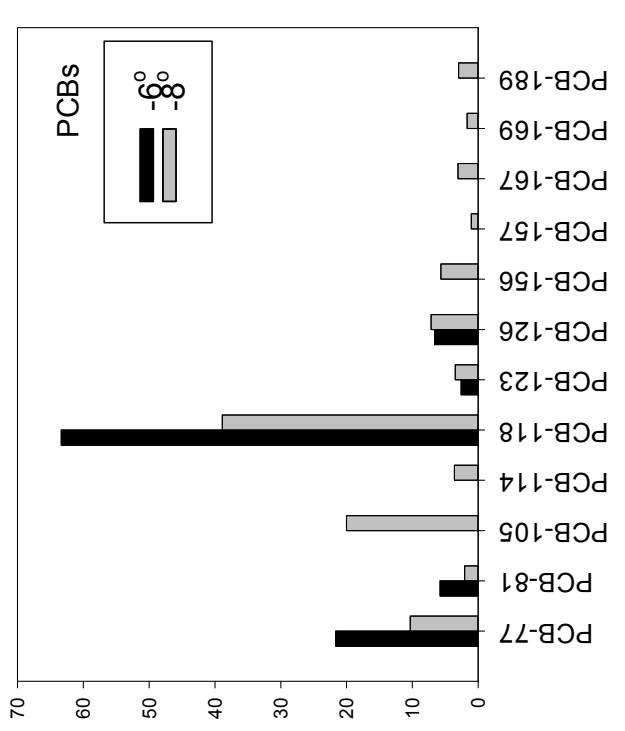

(\%) ио!̣อed

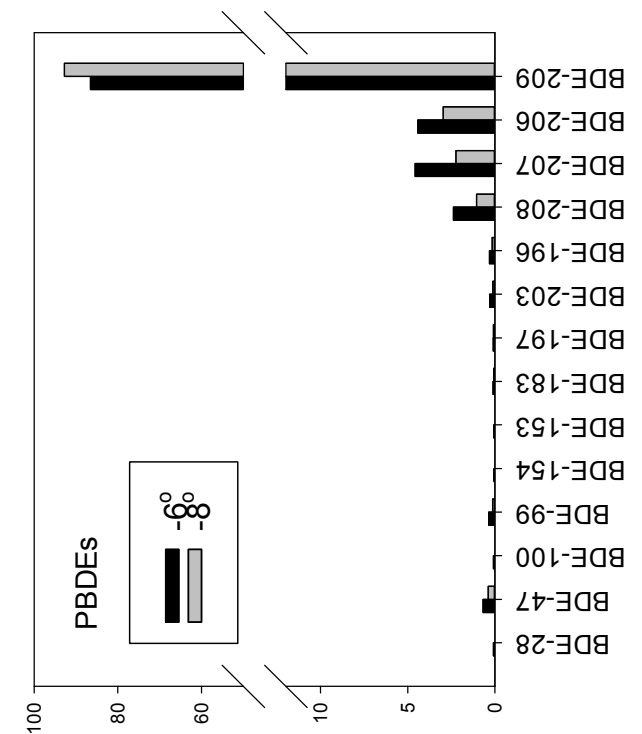

(\%) uo!̣oedy

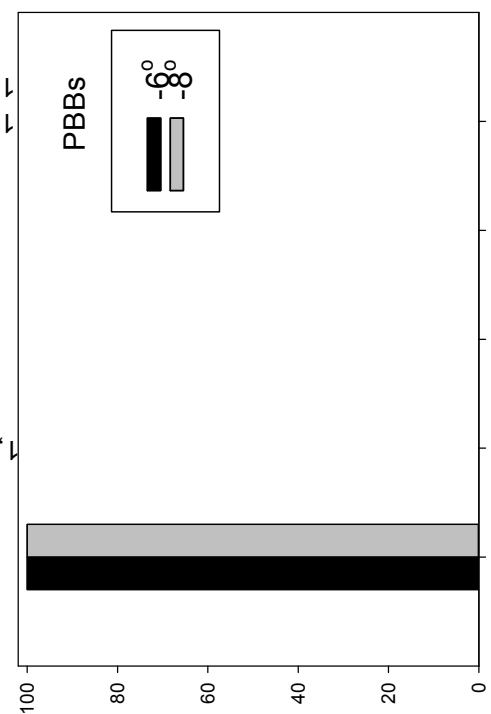

(\%) иопฺวеม

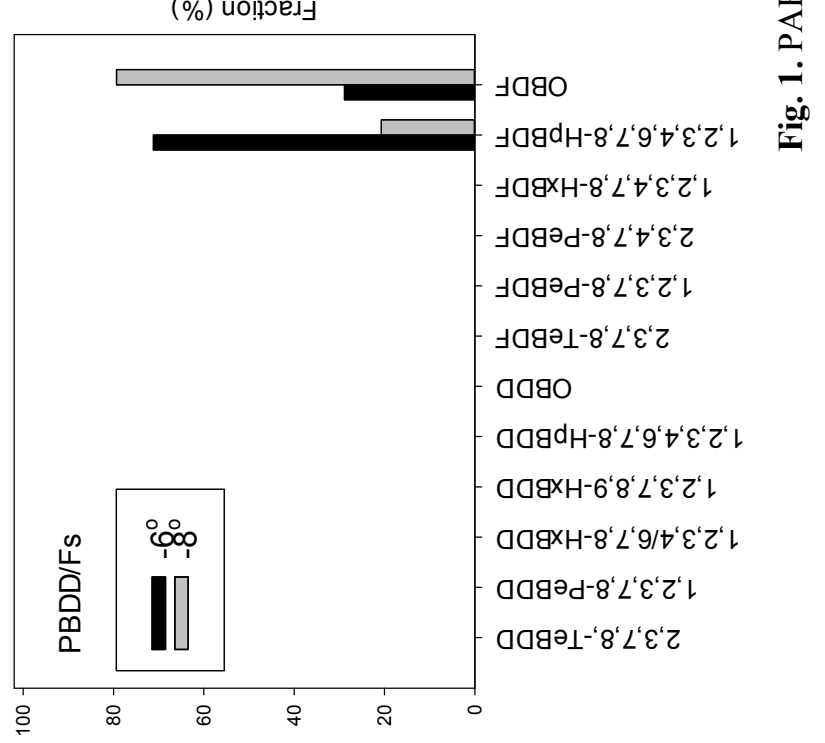

(\%) uo!̣oed」 


\section{CONCLUSIONS}

The toxic concentrations of PAHs and POPs during the $-6^{\circ}$ injection timing were $2-22$ times higher than those in $-8^{\circ}$ scenario. The increases were due to the reduced combustion efficiency that occurred during the retardation. The reduced combustion efficiency assertion was supported by the higher $\mathrm{CO}$ and $\mathrm{PM}$ emissions during retardation, which were 1.4 and 1.2 times higher than in $-8^{\circ}$ injection timing. The retardation of the injection timing was also found to influence the gas- and particle-phase partitioning of the organic compounds. We found that the retardation had more influence on these pollutants in the particlephase than in the gas-phase. The $-6^{\circ}$ injection timing had higher fractions of more toxic congeners than the $-8^{\circ}$ scenario, for example, the TeCDF mass fraction increased from $3.9 \%$ to $7.7 \%$, while that of PeCDFs increased from $10.8 \%$ to $12.8 \%$. This was the reason for the high BaPeq and WHO-TEQ concentrations measured during the $-6^{\circ}$ scenario. Therefore, it can be concluded that retarding the injection timing has a negative impact on PAH and POP emissions from diesel engines.

\section{ACKNOWLEDGMENTS}

The authors acknowledge the Ministry of Science and Technology, Taiwan, for supporting this work under Grant MOST 103-2221-E-230 -001 -MY3.

\section{REFERENCES}

Addink, R. and Altwicker, R.E. (2004). Formation of polychlorinated dibenzo- $p$-dioxins and dibenzofurans from chlorinated soot. Carbon 42: 2661-2668.

Agarwal, A.K., Srivastava, D.K., Dhar, A., Maurya, R.K., Shukla, P.C. and Singh, A.P. (2013). Effect of fuel injection timing and pressure on combustion, emissions and performance characteristics of a single cylinder diesel engine. Fuel 111: 374-383.

Agarwal, A.K., Dhar, A., Gupta, J.G., Kim, W.I., Lee, C.S. and Park, S. (2014). Effect of Fuel injection pressure and injection timing on spray characteristics and particulate size-number distribution in a biodiesel fuelled common rail direct injection diesel engine. Appl. Energy 130: 212-221.

Agarwal, D., Singh, S.K. and Agarwal, A.K. (2011). Effect of Exhaust Gas Recirculation (EGR) on performance, emissions, deposits and durability of a constant speed compression ignition engine. Appl. Energy 88: 29002907.

Alriksson, M. and Denbratt, I. (2006). Low temperature combustion in a heavy duty diesel engine using high levels of EGR. SAE Technical Paper 2006-01-0075.

Bell, M.L., McDermott, A., Zeger, S.L., Samet, J.M. and Dominici, F. (2004). Ozone and short-term mortality in 95 US urban communities, 1987-2000. JAMA 292: 2372-2378.

Chang, S.S., Lee, W.J., Wang, L.C., Chang-Chien, G.P. and Wu, C.Y. (2013). Energy recovery and emissions of
$\mathrm{PBDD} / \mathrm{F}$ and PBDEs from co-combustion of woodchip and wastewater sludge in an industrial boiler. Environ. Sci. Technol. 47: 12600-12606.

Chang, Y.C., Lee, W.J., Wang, L.C., Yang, H.H., Cheng, M.T., Lu, J.H., Tsai, Y.I. and Young, L.H. (2014a). Effects of waste cooking oil-based biodiesel on the toxic organic pollutant emissions from a diesel engine. Appl. Energy 113: 631-638.

Chang, Y.C., Lee, W.J., Yang, H.H., Wang, L.C., Lu, J.H., Tsai, Y.I., Cheng, M.T., Young, L.H. and Chiang, C.J. (2014b). Reducing emissions of persistent organic pollutants from a diesel engine by fueling with watercontaining butanol diesel blends. Environ. Sci. Technol. 48: 6010-6018.

Chen, C.Y., Lee, W.J., Mwangi, J.K., Wang, L.C. and Lu, J.H. (2017a). Impact of magnetic tube on pollutant emissions from the diesel engine. Aerosol Air Qual. Res. 17: 1097-1104.

Chen, C.Y., Lee, W.J., Mwangi, J.K., Wang, L.C., Wu, J.L. and Lin, S.L. (2017b). Reduction of persistent organic pollutant emissions during incinerator start-up by using crude waste cooking oil as an alternative fuel. Aerosol Air Qual. Res. 17: 899-912.

Chen, C.Y., Lee, W.J., Wang, L.C., Chang, Y.C., Yang, H.H., Young, L.H., Lu, J.H., Tsai, Y.I., Cheng, M.T. and Mwangi, J.K. (2017c). Impact of high soot-loaded and regenerated diesel particulate filters on the emissions of persistent organic pollutants from a diesel engine fueled with waste cooking oil-based biodiesel. Appl. Energ. 191: 35-43.

Chen, S., Cui, K., Zhu, J., Zhao, Y., Wang, L.C. and Mutuku, J.K. (2019). Effect of exhaust gas recirculation rate on the emissions of persistent organic pollutants from a diesel engine. Aerosol Air Qual. Res. 19: 812819.

Cheruiyot, N.K., Lee, W.J., Mwangi, J.K., Wang, L.C., Lin, N.H., Lin, Y.C., Cao, J., Zhang, R. and ChangChien, G.P. (2015). An overview: Polycyclic aromatic hydrocarbon emissions from the stationary and mobile sources and in the ambient air. Aerosol Air Qual. Res. 15: 2730-2762.

Cheruiyot, N.K., Lee, W.J., Yan, P., Mwangi, J.K., Wang, L.C., Gao, X., Lin, N.H. and Chang-Chien, G.P. (2016). An overview of $\mathrm{PCDD} / \mathrm{F}$ inventories and emission factors from stationary and mobile sources: What we know and what is missing. Aerosol Air Qual. Res. 16: 2965-2988.

Cheruiyot, N.K., Wang, L.C., Lin, S.L., Yang, H.H. and Chen, Y.T. (2017). Effects of selective catalytic reduction on the emissions of persistent organic pollutants from a heavy-duty diesel engine. Aerosol Air Qual. Res. 17: $1658-1665$.

Diao, C., Guo, X. and Li, J. (2018). Research on urea jet pump performance characteristics using the optimized $\mathrm{NO}_{\mathrm{x}}$ removal equipment in diesel engine. Aerosol Air Qual. Res. 18: 1886-1900.

Dober, G., Tullis, S., Greeves, G., Milovanovic, N., Hardy, M. and Zuelch, S. (2008). The impact of injection strategies on emissions reduction and power output of 
future diesel engines. SAE Technical Paper 2008-010941.

Gnanasekaran, S., Saravanan, N. and Ilangkumaran, M. (2016). Influence of injection timing on performance, emission and combustion characteristics of a DI diesel engine running on fish oil biodiesel. Energy 116: 12181229.

He, C., Ge, Y., Tan, J., You, K., Han, X. and Wang, J. (2010). Characteristics of polycyclic aromatic hydrocarbons emissions of diesel engine fueled with biodiesel and diesel. Fuel 89: 2040-2046.

Iino, F., Imagawa, T., Takeuchi, M. and Sadakata, M. (1999). De novo synthesis mechanism of polychlorinated dibenzofurans from polycyclic aromatic hydrocarbons and the characteristic isomers of polychlorinated naphthalenes. Environ. Sci. Technol. 33: 1038-1043.

Khaniabadi, Y.O., Goudarzi, G., Daryanoosh, S.M., Borgini, A., Tittarelli, A. and De Marco, A. (2017). Exposure to $\mathrm{PM}_{10}, \mathrm{NO}_{2}$, and $\mathrm{O}_{3}$ and impacts on human health. Environ. Sci. Pollut. Res. 24: 2781-2789.

Koebel, M., Elsener, M. and Kleemann, M. (2000). UreaSCR: A promising technique to reduce $\mathrm{NO}_{\mathrm{x}}$ emissions from automotive diesel engines. Catal. Today 59: 335345.

Kouremenos, D., Hountalas, D., Binder, K., Raab, A. and Schnabel, M. (2001). Using advanced injection timing and EGR to improve di diesel engine efficiency at acceptable no and soot levels. SAE Trans. 110: 55-68.

Kuo, Y.C., Chen, Y.C., Yang, J.H., Tsai, P.J., Wang, L.C. and Chang-Chien, G.P. (2012). Correcting the gas and particle partitioning of PCDD/F congeners in the flue gas of an iron ore sinter Plant. J. Hazard. Mater. 209: 402-407.

Kuo, Y.C., Chen, Y.C., Lin, M.Y., Young, L.H., Hsu, H.T., Liou, S.H., Wu, T.N., Wang, L.C. and Tsai, P.J. (2015). Ambient air concentrations of PCDD/Fs, coplanar PCBs, $\mathrm{PBDD} / \mathrm{Fs}$, and PBDEs and their impacts on vegetation and soil. Int. J. Environ. Sci. Technol. 12: 2997-3008.

Lai, Y.C., Tsai, C.H., Chen, Y.L. and Chang-Chien, G.P. (2017). Distribution and sources of atmospheric polycyclic aromatic hydrocarbons at an industrial region in Kaohsiung, Taiwan. Aerosol Air Qual. Res. 17: 776-787.

Laroo, C.A., Schenk, C.R., Sanchez, L.J., McDonald, J. and Smith, P.L. (2012). Emissions of PCDD/Fs, PCBs, and PAHs from legacy on-road heavy-duty diesel engines. Chemosphere 89: 1287-1294.

Liu, J., Yao, A. and Yao, C. (2014). Effects of injection timing on performance and emissions of a HD diesel engine with DMCC. Fuel 134: 107-113.

Mani, M. and Nagarajan, G. (2009). Influence of injection timing on performance, emission and combustion characteristics of a DI diesel engine running on waste plastic oil. Energy 34: 1617-1623.

McDonald, J.D., Campen, M.J., Harrod, K.S., Seagrave, J., Seilkop, S.K. and Mauderly, J.L. (2011). Engineoperating load influences diesel exhaust composition and cardiopulmonary and immune responses. Environ. Health Perspect. 119: 1136-1141.

Melymuk, L., Bohlin-Nizzetto, P., Prokeš, R., Kukučka, P. and Klánová, J. (2016). Sampling artifacts in active air sampling of semivolatile organic contaminants: Comparing theoretical and measured artifacts and evaluating implications for monitoring networks.. Environ. Pollut. 217: 97-106.

Mwangi, J.K., Lee, W.J., Chang, Y.C., Chen, C.Y. and Wang, L.C. (2015). An overview: Energy saving and pollution reduction by using green fuel blends in diesel engines. Appl. Energy 159: 214-236.

Mwangi, J.K., Lee, W.J., Wang, L.C., Sung, P.J., Fang, L.S., Lee, Y.Y. and Chang-Chien, G.P. (2016). Persistent organic pollutants in the Antarctic coastal environment and their bioaccumulation in penguins. Environ. Pollut. 216: 924-934.

Ni, Y., Zhang, H., Fan, S., Zhang, X., Zhang, Q. and Chen, J. (2009). Emissions of PCDD/Fs from Municipal solid waste incinerators in China. Chemosphere 75: 1153-1158.

Redfern, F.M., Lee, W.J., Yan, P., Mwangi, J.K., Wang, L.C. and Shih, C.H. (2017a). Overview and perspectives on emissions of polybrominated diphenyl ethers on a global basis: Evaporative and fugitive releases from commercial PBDE mixtures and emissions from combustion sources. Aerosol Air Qual. Res. 17: 1117-1131.

Redfern, F.M., Lin, S.L., Wang, L.C., Wu, J.L. and MP, E.M. (2017b). PBDE emissions during the start-up procedure of an industrial waste incinerator by the cocombustion of waste cooking oil and diesel fuel. Aerosol Air Qual. Res. 17: 975-989.

Sayin, C. and Canakci, M. (2009). Effects of injection timing on the engine performance and exhaust emissions of a dual-fuel diesel engine. Energy Convers. Manage. 50: 203-213.

Sindhu, R., Amba Prasad Rao, G. and Madhu Murthy, K. (2018). Effective reduction of $\mathrm{NO}_{\mathrm{x}}$ emissions from diesel engine using split injections. Alexandria Eng. $J$. 57: 1379-1392.

Wang, L.C., Lee, W.J., Lee, W.S., Chang-Chien, G.P. and Tsai, P.J. (2003). Effect of chlorine content in feeding wastes of incineration on the emission of polychlorinated dibenzo-p-dioxins/dibenzofurans. Sci. Total Environ. 302: 185-198.

Wang, L.C., Wang, I.C., Chang, J.E., Lai, S.O. and ChangChien, G.P. (2007). Emission of polycyclic aromatic hydrocarbons (PAHs) from the liquid injection incineration of petrochemical industrial wastewater. J. Hazard. Mater. 148: 296-302.

Wang, L.C., Lin, L.F. and Lai, S.O. (2009). Emissions of polycyclic aromatic hydrocarbons from fluidized and fixed bed incinerators disposing petrochemical industrial biological sludge. J. Hazard. Mater. 168: 438-444.

Wang, L.C., Hsi, H.C., Wang, Y.F., Lin, S.L. and ChangChien, G.P. (2010a). Distribution of polybrominated diphenyl ethers (PBDEs) and polybrominated dibenzo$p$-dioxins and dibenzofurans (PBDD/Fs) in municipal solid waste incinerators. Environ. Pollut. 158: 15951602.

Wang, L.C., Lee, W.J., Lee, W.S. and Chang-Chien, G.P. (2010b). Emission estimation and congener-specific characterization of polybrominated diphenyl ethers from 
various stationary and mobile sources. Environ. Pollut. 158: 3108-3115.

Wang, L.C., Lee, W.J., Lee, W.S. and Chang-Chien, G.P. (2011). Polybrominated diphenyl ethers in various atmospheric environments of Taiwan: Their levels, source identification and influence of combustion sources. Chemosphere 84: 936-942.

Wu, E.M.Y., Wang, L.C., Lin, S.L. and Chang-Chien, G.P. (2014). Validation and characterization of persistent organic pollutant emissions from stack flue gases of an electric arc furnace by using a long-term sampling system
(AMESA®). Aerosol Air Qual. Res. 14: 185-196.

Zeng, K., Huang, Z., Liu, B., Liu, L., Jiang, D., Ren, Y. and Wang, J. (2006). Combustion characteristics of a direct-injection natural gas engine under various fuel injection timings. Appl. Therm. Eng. 26: 806-813.

Received for review, March 11, 2019

Revised, April 12, 2019

Accepted, April 13, 2019 